\title{
Effectiveness of Using Trichoderma viride as Biosorbent for Remazol Brilliant Violet in Batik Wastewater Treatment
}

\author{
Anna Safitri ${ }^{1,2 *}$, Wiwin Dwi Febrianti ${ }^{1}$, Galuh Rahmaniah ${ }^{1}$ \\ ${ }^{1}$ Department of Chemistry, Faculty of Mathematical and Natuaral Sciences, Universitas Brawijaya \\ Jl Veteran, No 1, Malang, 65145, Indonesia \\ ${ }^{2}$ Research Center for Smart Molecules of Natural Genetic Resources (SMONAGENES) \\ Brawijaya University, Malang, 65145, Indonesia
}

Submission: April 2020; Revised: May 2020; Accepted: May 2020

*Corresponding author: Anna Safitri; e-mail: a.safitri@ub.ac.id; tel.: +62-341-575838

\begin{abstract}
Synthetic dyes used in the batik industry cause negative impacts on the environment. One type of synthetic dyes used in batik industry is remazol brilliant violet. This synthetic dye is reactive, carcinogenic, and non-biodegradable. Therefore, a strategy to degrade this synthetic dye is needed. In this study, the potential application of Trichoderma viride for biosorption of remazol brilliant violet (RBZ) in batik wastewater was investigated. The current work aimed on determination of the optimum conditions, including $\mathrm{pH}$, contact time, and RBZ concentration. Biosorption of RBZ was carried out at pH 4 to 9; with contact times of 12, 24, 30, 36, and $42 \mathrm{~h}$, with concentrations of dye solutions were 40, 60, 70, 80, and $90 \mathrm{mg} / \mathrm{L}$. The results showed that the optimum biosorption of RBZ was obtained at $\mathrm{pH} 4$, for $30 \mathrm{~h}$, and the optimum concentration of RBZ at $60 \mathrm{mg} / \mathrm{L}$, with the RBZ absorbed was $79.27 \%$. The FTIR analysis suggested that RBZ biosorption changed the chemical functional groups in the T. viride. The FTIR spectra revealed that the biomolecules that were affected during the process of biosorption were mainly lipids and proteins, and slightly from nucleic acids and carbohydrates.
\end{abstract}

Keywords: Biosorption, FTIR analysis, RBZ, Trichodema viride

\section{INTRODUCTION}

Batik is one of the works of Indonesian art that still exists and continues to be used. Since batik has been selected as one of the Masterpieces of the Oral and Intangible Heritage of Humanity by UNESCO on October 2, 2009, the batik industry is increasingly favored by Indonesian and also foreign communities. There are currently around 4.5 million batik industry businesses in Indonesia [1]. Most batik industries use synthetic dyes because they are affordable, durable, and easy to use. However, artificial chemical dyes usually are large complex compound that cause them difficult to degrade and can persist in the environment for a long time period [2].

One of the synthetic dyes that are widely used in the batik industry is remazol dyes. Remazol violet $5 R$ is a reactive dye from the azo group [3]. Azo dyes are very reactive and do not fade easily because they have chromophore groups (as color carriers) and auxochrome groups (as color binders). In addition, this dye also has a stable aromatic complex structure that is resistant to chemical oxidation reactions [3]. This dye can be harmful, as it causes skin irritation, affect to the respiratory system and digestive tract [4].

The methods used to reduce the intensity of dyes in wastewater include coagulation, filtration, electro-decolorization, flocculation, and coagulation [5, 6]. Nonetheless, these applications result in a vast chemical sludge production or noneconomical to operate. Therefore, it is essential to protect the water reserves by searching a green and reasonable solution.

Biosorption is the latest wastewater treatment technology that can remove metals and toxic dyes [7]. The biosorption process can occur due to the presence of biological materials called biosorbent and the presence of a solution with high affinity, thus, this is easily bound to biosorbents. Biosorbents used can be fungi, bacteria, algae and biopolymers [8].

Decolorization of dyes can use fungi, since fungi produce extracellular ligninolytic enzymes that are able to remove aromatic compounds and degrade various organic and inorganic contaminants [7]. Studies that have been carried out using fungi as a dye biosorbent include using Coriolus versicolor for decolorization of brilliant 
violet remazol [9] and Aspergillus sp for indigosol blue-04B biodegradation [10].

In a previous study [11], the use of immobilized T. viride on Ca-alginate for RBZ biosorption has been applied. The biosorption process resulted in the optimum condition of $60 \mathrm{~min}, \mathrm{pH} 4$, with percent of adsorption was $8.76 \%$. In this study, $T$. viride is directly used to conduct biosorption process of RBZ dye, without immobilization. Therefore, in particular, the objectives of the present work are to determine the influences of time, $\mathrm{pH}$, and concentration on the RBZ biosorption process using $T$. viride.

\section{METHODS}

\section{Trichoderma viride Cultivation}

PDA (potatoes dextrose agar) from SigmaAldrich was used as a solid growth medium for $T$. viride sub-culturing and adaptation. A loop full of the culture of $T$. viride was cultivated in the sterilized PDA incubated for 6-8 days, at $37^{\circ} \mathrm{C}$. Subsequently, T. viride spores appeared in the PDA media was dispersed in 1-2 $\mathrm{mL}$ of sterilized bi-distilled water. These spores were then moved to a broth growth medium $(100 \mathrm{~mL})$ in $250-\mathrm{mL}$ Erlenmeyer flasks on a rotary shaker, and grown at ambient temperature, at a speed of $150 \mathrm{rpm}$, for $40 \mathrm{~h}$. The suspension collected as $T$. viride inoculum and will be used for the biosorption process.

\section{The Biosorption Process of RBZ}

A six-solution of $40 \mathrm{mg} / \mathrm{L} \mathrm{RBV}$ was adjusted to $\mathrm{pH} \mathrm{4,} \mathrm{5,} \mathrm{6,} \mathrm{7,} \mathrm{8,} \mathrm{and} 9$ respectively using a $\mathrm{pH}$ meter. The $\mathrm{pH}$ was accustomed by the $0.1 \mathrm{M} \mathrm{HCl}$ or $0.1 \mathrm{M}$ $\mathrm{NaOH}$ addition into those solutions. A $25 \mathrm{~mL}$ of 40 $\mathrm{mg} / \mathrm{L} \mathrm{RBV}$ solution with $\mathrm{pH}$ of $4,5,6,7,8$, and 9 were contacted with $20.0 \mathrm{~mL} \mathrm{~T}$. viride inoculum. Then the solution mixture was incubated until the mid-logarithmic phase $(36 \mathrm{~h})$. For the time influence, the biosorption process was conducted as follows, a total of $25 \mathrm{~mL}$ of $40 \mathrm{mg} / \mathrm{L} \mathrm{ppm} \mathrm{RBV}$ solution with optimum $\mathrm{pH}$ was contacted with 20.0 $\mathrm{mL}$ of $T$. viride inoculum. The biosorption process was conducted int the time variations of $12 \mathrm{~h}, 24 \mathrm{~h}$, $30 \mathrm{~h}, 36 \mathrm{~h}$, and $42 \mathrm{~h}$.

For the concentration variation, biosorption process was applied in the same methods, using various RBZ concentrations of 40,60, 70, 80, and $90 \mathrm{mg} / \mathrm{L}$, in the optimum $\mathrm{pH}$ and time contact time, using a $20 \mathrm{~mL} \mathrm{~T}$. viride inoculum. Next, after all the biosorption process finished, the solution was filtered using Whatman filter paper no. 40 to separate $T$. viride from the filtrate. The resulted filtrate was then measured its absorbance using a UV-visible spectrophotometer (1601-Shimadzu). The resulted solid from the filtration process was kept and then was analyzed by FTIR spectrophotometer (8400S/Shimadzu). All process was conducted in triplicates. The calculation of the number of RBZ during the biosorption process was determined using this equation:

$$
\% \text { of biosorption }=[(\mathrm{Ca}-\mathrm{Cb})] / \mathrm{Ca} \times 100 \%
$$

where

$C a=$ concentration before biosorption $(\mathrm{mg} / \mathrm{L})$

$\mathrm{Cb}=$ concentration after biosorption $(\mathrm{mg} / \mathrm{L})$.

\section{Statistical Analysis}

Data was analyzed using the ANOVA with a level of confidence of $\alpha=0.05$, and the differences between variation with student's $T$ test.

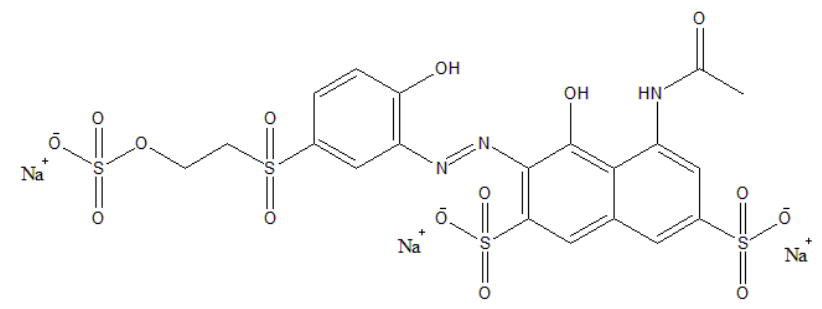

Figure 1. The chemical structure of remazol brilliant violet dye.

\section{RESULTS AND DISCUSSIONS}

The effect of $\mathrm{pH}$ on the biosorption process of $\mathrm{RBZ}$ on $T$. viride is shown in Figure 2. There was a decrease from $\mathrm{pH} 4$ to $\mathrm{pH} 9$, in the biosorption of RBZ. In the acidic condition or at low $\mathrm{pH}$, the biosorbent surfaces are protonated, since $\mathrm{H}^{+}$ion is abundant in acidic condition. The $\mathrm{pH}$ of the medium affects both the solubility of RBZ and ionization of the functional chemical groups including $-\mathrm{COO}^{-},-\mathrm{OPO}_{3}{ }^{4-}$, and $-\mathrm{NH}^{-}$, of the cell walls of $T$. viride [12]. These functional groups have negative charges, and thus, they are acidic. Moreover, in the low $\mathrm{pH}$, less than 7, the protonated adsorbent can result in the electrostatic interaction between adsorbent and the RBZ; considering RBZ has a negative $-\mathrm{S}$ group and hence, is an anionic dye.

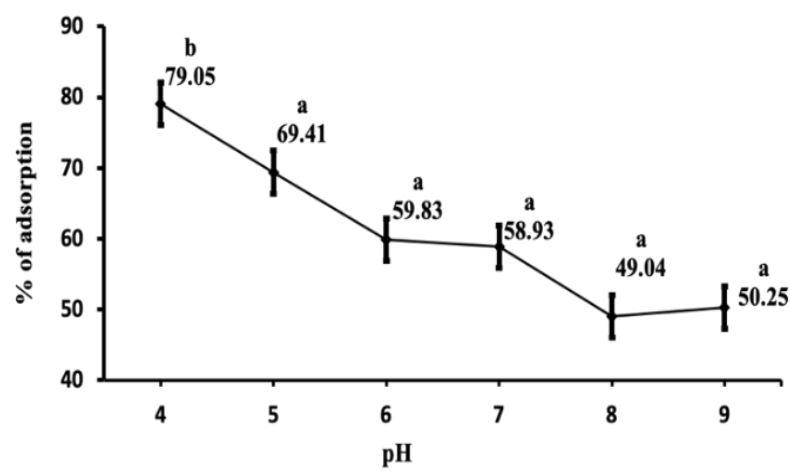

Figure 2. The RBZ biosorption in the $\mathrm{pH}$ variations of $\mathrm{pH}$ 4 to PH 9. 
A previous study of RBV biosorption using periwinkle shell resulted in decreasing adsorption along with increasing of the $\mathrm{pH}[10]$. Another study by Rapo, et. al., 2019 [3] on the RBZ biosorption using calcinated egg skin resulted in the highest adsorption rate at $\mathrm{pH}$. These studies were in agreement with the results of our current work, that at the low $\mathrm{pH}$ causing the adsorbent surfaces were surrounded by protonated $\mathrm{H}^{+}$ion. The statistical analysis showed that from $\mathrm{pH} 5$ to $\mathrm{pH}$ 9 , the adsorption percentage was not different significantly $(p<0.05)$. Hence, $\mathrm{pH} 4$ was chosen as the optimum $\mathrm{pH}$ for the biosorption process, with the number of RBZ adsorbed was $79.05 \%$.

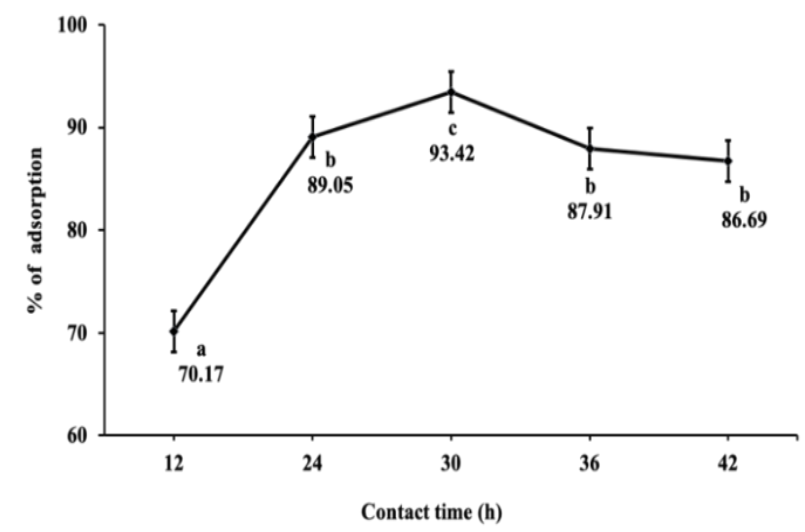

Figure 3. The RBZ biosorption in the time variations of 12 to $42 \mathrm{~h}$.

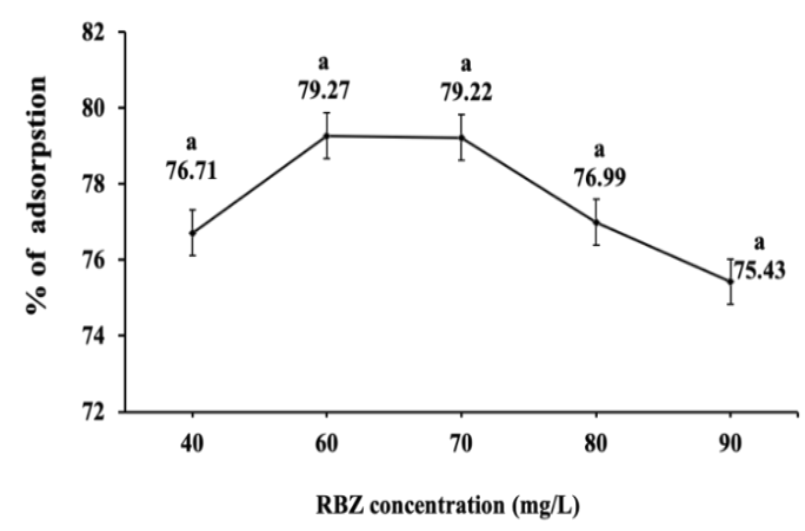

Figure 4. The RBZ biosorption in the variations of RBZ concentration of 40 to $90 \mathrm{mg} / \mathrm{L}$.

Biosorption of the dye increased from 12 to 30 $\mathrm{h}$, then the number of RBZ adsorbed declined from 30 to the end of the process. As a result, the optimum time for biosorption process was $30 \mathrm{~h}$, with the RBZ adsorbed was at $93.42 \%$ (Figure 3). The RBZ biosorption experiment was a two-steps adsorption. At first, biosorption occurred fast, because the active sites of the adsorbent were unoccupied, from 12 to $30 \mathrm{~h}$. Next, from 30 to 42 $\mathrm{h}$, the balance of adsorption and desorption reached. Consequently, the biosorption rate decreased, due to the active sites were already fulfilled with the dye. It was suggested that RBZ biosorption was as a result of simply physicochemical interactions between $T$. viride and RBZ solution [13]. In addition, the kinetics of RBZ biosorption involved no energy-mediated reactions.

On the variations of RBZ concentration, percent adsorption was $76.71 \%$ in a solution of 40 $\mathrm{mg} / \mathrm{L}$. Then at a concentration of $60 \mathrm{mg} / \mathrm{L} \mathrm{RBZ}$ adsorption was $79.27 \%$, at concentrations of 70,80 , and $90 \mathrm{mg} / \mathrm{L}$ percent of adsorption were $79.22 \%$, $76.99 \%$, and $75.43 \%$, respectively (Figure 4). From Figure 4, it was shown that from the concentration of 40 to $60 \mathrm{mg} / \mathrm{L}$ the number of RBZ adsorbed increased; then decreased at the concentration of 70 to $90 \mathrm{mg} / \mathrm{L}$. The difference in the amount of RBZ adsorption related to the toxicity of the dyes. The toxicity of azo dyes increases with increasing concentration. Therefore, the rate of adsorption keeps increasing to a certain concentration; and subsequently decreases with increasing dye toxicity [14]. However, statistical analysis results revealed that there were no significant differences between variations in the concentration of 40 to 90 $\mathrm{mg} / \mathrm{L}$, ppm because they had the same notation. Consequently, the RBZ concentration did not affect to the biosorption process.

Results from FTIR analysis are shown in Figure 5 , and the assignment of the band of interest is listed in Table 1. It is shown in Figure 5 that there were no significant wavenumber shifts. According to Ratnawati et.al. (2010) [15] proteins and polysaccharides play an important role in the process of ion biosorption where covalent bonds occur including amino and carboxyl groups. Before biosorption process, there was absorption band at $1649.02 \mathrm{~cm}^{-1}$ indicated the presence of the $\mathrm{C}=\mathrm{O}$ amide group on $T$. viride. Another band that appeared at $1546.80 \mathrm{~cm}^{-1}$ indicated the presence of -NH from amide group. At a wavenumber 3429.20 $\mathrm{cm}^{-1}$ which shows the absorption band of the $\mathrm{O}-\mathrm{H}$ from carboxyclic group. This group is a signature of proteins. After the biosorption, there was a wavenumber at $1652.88 \mathrm{~cm}^{-1}$, assigned as the $\mathrm{C}=$ $\mathrm{O}$ carbonyl, and this band was supported by the absorption band at a wave number of $1652.88 \mathrm{~cm}^{-}$ ${ }^{1}$, indicating the presence of $-\mathrm{N}-\mathrm{H}$ from amide group. Finally, a wavenumber at $3402.20 \mathrm{~cm}^{-1}$, which shows the absorption band of the carboxylic $\mathrm{O}-\mathrm{H}$ group. T. viride that have been contacted with RBV analyzed by FTIR showed changes in intensity in the absorption bands, but there were still the same functional groups as T. viride. From the FTIR analysis, it is suggested that the biosorption of RBV did not damage the structure of T. viride. 


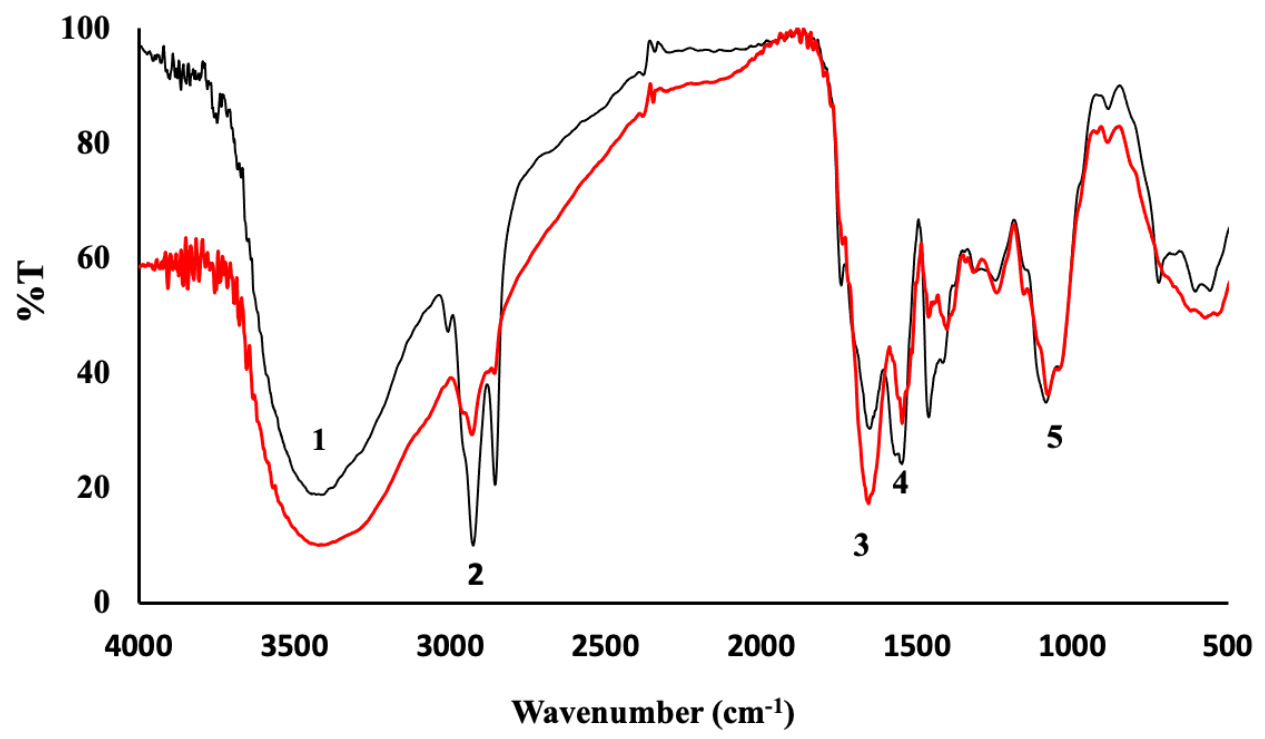

Figure 5. The FTIR spectra T. viride before (black line) and after (red line) biosorption process of $40 \mathrm{mg} / \mathrm{L} \mathrm{RBZ} \mathrm{at} \mathrm{pH} 4$, for $30 \mathrm{~h}$, at ambient temperature.

Table 1. Analysis of functional groups in T. viride before and after biosorption of RBZ

\begin{tabular}{|c|c|c|c|c|}
\hline \multirow{2}{*}{ No. } & \multicolumn{2}{|c|}{ Before Biosorption } & \multicolumn{2}{|c|}{ After Biosorption } \\
\hline & Wavenumber $\left(\mathrm{cm}^{-1}\right)$ & Designation & Wavenumber $\left(\mathrm{cm}^{-1}\right)$ & Designation \\
\hline 1 & 3429.20 & $\begin{array}{c}\mathrm{O}-\mathrm{H} \\
\text { Carboxylate }\end{array}$ & 3402.20 & $\begin{array}{c}\text { O-H } \\
\text { Carboxylate }\end{array}$ \\
\hline 2 & 2923.38 & $\begin{array}{c}\text { C-H } \\
\text { alkene }\end{array}$ & 2927.74 & $\begin{array}{c}\text { C-H } \\
\text { alkene }\end{array}$ \\
\hline 3 & 1649.02 & $\begin{array}{l}\mathrm{C}=\mathrm{O} \\
\text { amide }\end{array}$ & 1652.88 & $\begin{array}{l}\mathrm{C}=\mathrm{O} \\
\text { amide }\end{array}$ \\
\hline 4 & 1546.80 & $\begin{array}{c}\mathrm{N}-\mathrm{H} \\
\text { amide }\end{array}$ & 1544.88 & $\begin{array}{c}\mathrm{N}-\mathrm{H} \\
\text { amide }\end{array}$ \\
\hline 5 & 1083.92 & $\begin{array}{c}\mathrm{C}-\mathrm{N} \\
\text { amide }\end{array}$ & 1076.21 & $\begin{array}{c}\mathrm{C}-\mathrm{N} \\
\text { amide }\end{array}$ \\
\hline
\end{tabular}

\section{CONCLUSION}

The current work has shown that the biosorption process of $\mathrm{RBZ}$ using $T$. viride was affected by $\mathrm{pH}$ and time. In this study, optimum conditions were achieved at $\mathrm{pH} 4$ with a contact time of $30 \mathrm{~h}$, and at a concentration of dye solution of $40 \mathrm{mg} / \mathrm{L}$, with percent adsorption was $76.27 \%$. The use of $T$. viride for the biosorption process of synthetic dye RBZ can be used as one of the green techniques for synthetic dye degradation in batik wastewater.

\section{ACKNOWLEDGEMENT}

Author thank to the facility that provided by the Biochemistry Laboratory, Chemistry Department, Brawijaya University.

\section{REFERENCES}

1. Wihardi, D. Pratikto, R.G. Kristanty, S. 2015. Pergeseran Makna Motif Batik Yogyakarta-
Surakarta. Jurnal Ilmiah Komunikasi Makna. 5(2); 2087-2461

2. Susanty, A. Hartini, S. Puspitasari, D. Arsiwi, P. 2015, Measuring Efficiency of Using Resource in the Production Process of Making StampedBatik: A DEA Approach. Mediterr. J. Soc. Sci. 6(2); 318-327.

3. Rápó, E. Posta, K. Suciu, M. Szép, R. Tonk, S. 2019. Adsorptive Removal of Remazol Brilliant Violet-5R Dye from Aqueous Solutions using Calcined Eggshell as Biosorbent, Acta Chim. Slov. 66; 648-658.

4. Robinson, T. Chandran, B. Nigam, P. 2002. Removal of dyes from a synthetic textile dye effluent by biosorption on apple pomace and wheat straw, Water Research. 36(11); 2824 - 2830.

5. Adnan, L.A. Hadibarata, T. Sathishkumar, P. Mohd Yusoff, AR. 2016. Biodegradation pathway of Acid Red 27 by white rot fungus Armillaria sp. F022 and phytotoxicity evaluation. Clean: Soil Air Water. 44;239-246

6. Sathishkumar, P. Kamala-Kannan, S. Cho, M. Kim, JS. Hadibarata, T. Salim, MR. Oh, B.T. 
2014. Laccase immobilization on cellulose nanofiber: the catalytic efficiency and recyclic application for simulated dye effluent treatment. J Mol Catal B Enzym. 100;111-120.

7. Tastan, B.E. Ertugrul, S. Donmez, G. 2010. Effective bioremoval of reactive dye and heavy metals by Aspergillus versicolor. Bioresour. Technol. 101; 870-876.

8. Safitri, A., Mahardini, P. Prasetyawan, S. Roosdiana, A. 2018. Biosorption of $\mathrm{Cr}(\mathrm{VI})$ in Aqueous Solution using Microorganisms: Comparison of the Use of Rhizopus oryzae, Bacillus firmus, and Trichoderma viride. IOP Conf. Series: Mat Sci Eng. 299;012023 (8 pages).

9. Sanghi, R. Awantika, D. Guha, S. 2006, Sequential batch culture studies for the decolorosation of reactive dye by Coriolus versicolor, Bioresource Technology, 97(3); 396-400.

10. Bello, O.S. Ahmad, M.A. 2011, Remavol of Remazol Brilliant Violet-5R dye using periwinkle shells. Journal Chemistry and Ecology. 21(5); 481-492.

11. Rahmaniah, G. Mahdi, C. Safitri, A. 2019. Biosorption of Synthetic Dye from Batik Wastewater Using Trichoderma viride Immobilized on Ca-Alginate. Journal of Physics: Conference Series. 1374; 012007 (6 pages).

12. Prasad, A.S. Varatharaju, G. Anushri, C. Dhivyasree, S. 2013. Biosorption of lead by Pleurotus florida and Trichoderma viride. $\mathrm{Br}$ Biotechnol J.3(1);66-78.

13. Gadd, G.M. 2009. Biosorption: critical review of scientific rationale, environmental importance and significance for pollution treatment. J. Chem. Technol. Biotechnol. 84;13-28.

14. Ratnawati, E. Rahyani, E. Naimah, S. 2010. Biosorption Technology by Microorganisms, an alternative Solution for Decrease Heavy Metal Pollution, Jurnal Kimia dan Kemasan. 32(1); 34-40 